\title{
Participation of Cytosolic Protein Phosphatase in Regulation of NADPH Oxidase in Polymorphonuclear Leukocytes
}

\author{
Naoko Kawakami, ${ }^{* a}$ Hiroaki Takemasa, ${ }^{a}$ Naoki Okamura, ${ }^{b}$ Takao Hayakawa, ${ }^{c}$ Shun Shimohama, ${ }^{d}$ \\ and Sadaki FuлIMOTo ${ }^{a}$ \\ Department of Environmental Biochemistry, Kyoto Pharmaceutical University, ${ }^{a}$ Misasagi, Yamashina-ku, Kyoto 607-8414, \\ Japan, Department of Physiological Chemistry, Hiroshima University School of Medicine, ${ }^{b}$ Kasumi, Minami-ku, Hiroshima \\ 734-0037, Japan, Division of Biological Chemistry and Biologicals, National Institute of Health Sciences, ${ }^{c}$ Kamiyoga, \\ Setagaya-ku, Tokyo 158-8501, Japan, and Department of Neurology, Faculty of Medicine, Kyoto University, ${ }^{\prime} 54$ Shogoin- \\ Kawaharacyo, Kyoto 606-8507, Japan. Received September 30, 1998; accepted February 12, 1999
}

Calyculin A, a protein phosphatase inhibitor, enhanced phorbol 12-myristate 13-acetate (PMA)-induced superoxide anion $\left(\mathrm{O}_{2}^{-}\right)$production and translocation of the cytosolic NADPH oxidase factor, p47phox, to the plasma membrane in guinea pig polymorphonuclear leukocytes (PMNs). When PMNs were treated with 1-(5-isoquinoline-sulfonyl)-3-methyl-piperazine (H-7), a protein kinase $\mathrm{C}(\mathrm{PKC})$ inhibitor, after exposure to PMA, inhibition of $\mathrm{O}_{2}^{-}$production and of translocation of $\mathrm{p47}$ phox to the membrane fraction in PMA-stimulated PMNs were observed. When calyculin $A$ was added to the PMA-stimulated PMNs after the addition of $\mathrm{H}-7, \mathrm{O}_{2}^{-}$production was again observed, and translocation of p47phox to the membrane fraction also occurred. The activity of NADPH oxidase, the amount of p47phox and the level of phosphorylation of p47phox in the membrane fraction prepared from PMA-stimulated PMNs, were reduced by the addition of the cytosol fraction from unstimulated PMNs. These reductions were attenuated by calyculin A. These results indicate that the active form of NADPH oxidase in PMNs can be reconstituted after the active complex of the enzyme has disappeared once, and that one of the mechanisms of regulation of this enzyme activity involves the phosphorylation of p47phox in the cyotosol and dephosphorylation of phosphorylated p47phox in the NADPH oxidase complex by protein kinase and protein phosphatase, respectively.

Key words polymorphonuclear leukocyte; NADPH oxidase; calyculin A; protein phosphatase

Polymorphonuclear leukocytes (PMNs) play an important role in host defence against microbial infections. Exposure of PMNs to a variety of stimuli results in activation of NADPH oxidase, during which reactive species such as superoxide anion $\left(\mathrm{O}_{2}^{-}\right)$and hydrogen peroxide $\left(\mathrm{H}_{2} \mathrm{O}_{2}\right)$ are generated. ${ }^{1,2)}$ To activate NADPH oxidase, at least four different proteins are required: membrane-bound cytochrome $\mathrm{b}_{558}, \mathrm{p} 47 \mathrm{phox}$, p67phox and Rac. ${ }^{3)}$ It is generally thought that p47phox and p67phox are translocated to the plasma membrane from the cytosol through phosphorylation of $\mathrm{p} 47 \mathrm{phox}$ by protein kinase $\mathrm{C}(\mathrm{PKC}){ }^{1-9)}$ Although a large number of studies on the mechanism of activation of NADPH oxidase have been described, little is known about regulation of the activity of the activated NADPH oxidase. Ding and Badwey ${ }^{10)}$ reported the existence of a phosphorylation dephosphorylation cycle of $\mathrm{p} 47$ phox that may regulate NADPH oxidase activation. Thus, they showed that type 1 and/or $2 \mathrm{~A}$ protein phosphatase inhibitors block the dephosphorylation of p47phox and may modulate $\mathrm{O}_{2}^{-}$release, and that these phosphatases may therefore serve as potential targets for enhancing the oxygendependent killing mechanisms of phagocytic leukocytes. Yamaguchi et al ${ }^{11,12)}$ also reported that an inactivation mechanism for activated NADPH oxidase may exist, and that cytosolic protein phosphatase may be involved in the inactivation of this enzyme. However, it has not been examined whether p47phox can again be translocated to the plasma membrane and whether the ability to produce $\mathrm{O}_{2}^{-}$can be restored once $\mathrm{p} 47 \mathrm{phox}$ has been diverted from the plasma membrane and loss of NADPH oxidase activity has occurred. In this report, we show that phorbol 12-myristate 13-acetate (PMA)-induced $\mathrm{O}_{2}^{-}$production and translocation of $\mathrm{p} 47 \mathrm{phox}$ to the membrane fraction in guinea pig PMNs is enhanced by calyculin A, a Ser/Thr protein phosphatase inhibitor, ${ }^{13,14)}$ and that the NADPH oxidase activity, the amount of $\mathrm{p} 47 \mathrm{phox}$ and the phosphorylation level of $\mathrm{p} 47 \mathrm{phox}$ in the membrane fraction prepared from PMA-stimulated PMNs, are decreased by the addition of the cytosol fraction obtained from resting PMNs. Further, we show that inactivation of NADPH oxidase, disappearance of $\mathrm{p} 47 \mathrm{phox}$ from the membrane fraction and dephosphorylation of phosphorylated p47phox are also suppressed by calyculin A.

\section{MATERIALS AND METHODS}

Materials Cytochrome C (type III), catalase, superoxide dismutase (SOD), PMA, and NADPH were purchased from Sigma (St. Louis, MO), 1-(5-isoquinoline-sulfonyl)-3-methylpiperazine (H-7) from Seikagaku Co. (Tokyo, Japan), calyculin $\mathrm{A}$, staurosporine and ( $p$-amidinophenyl)methanesulfonyl fluoride hydrochloride ( $p$-APMSF) from Wako Pure Chemicals (Osaka, Japan), and $\left.{ }^{32} \mathrm{P}\right]$ orthophosphate from ARC (St. Louis, MO). Anti-mouse p47phox antibody was generated against the 24-amino acid COOH-terminal peptide, PRPSSDLILHRCTESTKRKLTSAV, and was characterized previously. ${ }^{12)}$ All other chemicals used were of reagent grade and were obtained commercially.

Preparation of PMNs Guinea pig PMNs were obtained from casein-induced peritoneal exudates from female Hartley strain guinea pigs as described previously. ${ }^{15)}$

Prelabeling of PMNs with ${ }^{32} \mathbf{P}$ PMNs were labeled with carrier-free $\left[{ }^{32} \mathrm{P}\right]$ orthophosphate in Hanks' Pipes phosphatefree buffer containing $16 \mathrm{~mm}$ Pipes, $137 \mathrm{~mm} \mathrm{NaCl}, 5.4 \mathrm{~mm}$ $\mathrm{KCl}, 1.28 \mathrm{~mm} \mathrm{CaCl}_{2}, 0.81 \mathrm{~mm} \mathrm{MgSO}_{4}$, and $5.5 \mathrm{~mm}$ glucose (pH 7.3) as described previously. ${ }^{16)}$ 
Stimulation of PMNs and $\mathrm{O}_{2}^{-}$Determination $\mathrm{O}_{2}^{-}$production by PMNs was measured on the basis of the reduction of ferricytochrome $\mathrm{c}$ by the anion produced. In brief, PMNs $\left(10^{7}\right.$ cells $\left./ \mathrm{ml}\right)$ were preincubated in the presence or absence of calyculin A in Hanks' balanced salt solution (HBSS) (pH 7.4) at $37^{\circ} \mathrm{C}$ for $5 \mathrm{~min}$, and then $32 \mathrm{~nm}$ PMA was added. After further incubation for the indicated times, aliquots of the cell suspension were withdrawn and assayed for $\mathrm{O}_{2}^{-}$production. Staurosporine, a PKC inhibitor, was added to prevent further activation of PMNs by endogenous stimuli during the assay. The cell suspensions were added to mixtures containing cytochrome $\mathrm{c}(50 \mu \mathrm{M})$ and staurosporine (100 $\mathrm{ng} / \mathrm{ml}$ ) in HBSS (final volume, $1 \mathrm{ml}$ ) and incubated for $5 \mathrm{~min}$ at $37^{\circ} \mathrm{C}$. SOD $(10 \mu \mathrm{g})$ was added to stop the reaction, and the supernatant was separated by centrifugation. In the control, SOD was added before the addition of PMA. Reduced cytochrome $\mathrm{c}$ in the supernatant was measured on the basis of the increase in absorbance at $550 \mathrm{~nm}$, and $\mathrm{O}_{2}^{-}$generation was estimated by using an absorption coefficient of 19.1 $\mathrm{mM}^{-1} \mathrm{~cm}^{-1}$ at $550 \mathrm{~nm}^{17)}$ for the reduction of cytochrome c.

Assays for $\mathrm{O}_{2}^{-}$Production and for $\mathrm{p47phox}$ after Treatment of PMNs with PMA PMNs $\left(10^{7}\right.$ cells $\left./ \mathrm{ml}\right)$ were incubated with PMA ( $32 \mathrm{nM})$ in the presence or absence of calyculin $\mathrm{A}$ in HBSS at $37^{\circ} \mathrm{C}$. After incubation for the duration indicated, aliquots of cell suspensions were assayed for $\mathrm{O}_{2}^{-}$ production and $\mathrm{p} 47$ phox. $\mathrm{O}_{2}^{-}$produced was determined as described above. Samples for immunochemical detection of p47phox were prepared as follows. The cell suspensions were centrifuged $(100 \mathrm{~g}, 5 \mathrm{~min})$ and the precipitated cells were resuspended in relaxation buffer ( $10 \mathrm{~mm}$ Pipes, $\mathrm{pH} 7.3$, containing $100 \mathrm{~mm} \mathrm{KCl}, 3 \mathrm{~mm} \mathrm{NaCl}, 3.5 \mathrm{mM} \mathrm{MgCl}_{2}, 1.25 \mathrm{~mm}$ EGTA, $20 \mu \mathrm{g} / \mathrm{ml}$ leupeptin, $20 \mu \mathrm{g} / \mathrm{ml}$ pepstatin and $3 \mathrm{~mm} p$ APMSP) ${ }^{18)}$ containing $5 \mathrm{~mm}$ EDTA, $10 \mathrm{~mm} \mathrm{NaF}$ and $200 \mathrm{~nm}$ calyculin $A$ and then sonicated. The supernatant was separated by centrifugation $(85000 \mathrm{~g}, 30 \mathrm{~min})$ and the precipitate, the plasma membrane fraction, was suspended in relaxation buffer containing $0.34 \mathrm{M}$ sucrose and analyzed immunochemically for 47 phox as described below.

Preparation of Cytosol Fractions PMNs suspended in relaxation buffer $\left(10^{7}\right.$ cells $\left./ \mathrm{ml}\right)$ were disrupted by sonication. Undisrupted cells and nuclei were pelleted by centrifugation at $100 \mathrm{~g}$ for $5 \mathrm{~min}$ at $4{ }^{\circ} \mathrm{C}$. The supernatant was then centrifuged at $85000 \mathrm{~g}$ for $30 \mathrm{~min}$ at $4^{\circ} \mathrm{C}$, and the resulting supernatant is designated as "cytosol fraction" in later parts of this report.

Preparation of NADPH Oxidase-Rich Membrane Fractions After treatment of PMNs $\left(10^{7}\right.$ cells $\left./ \mathrm{ml}\right)$ with $320 \mathrm{nM}$ PMA for $3 \mathrm{~min}$ at $37^{\circ} \mathrm{C}$, cells were separated by centrifugation $(100 \mathrm{~g}, 5 \mathrm{~min})$ at $4{ }^{\circ} \mathrm{C}$ and were resuspended in ice-cold relaxation buffer containing $5 \mathrm{~mm}$ EDTA, $10 \mathrm{mM} \mathrm{NaF}$ and $200 \mathrm{nM}$ calyculin A. After sonication of the cell suspension, the precipitate was separated by centrifugation $(85000 \mathrm{~g}, 30$ $\min$ at $4{ }^{\circ} \mathrm{C}$ ) and resuspended in the above relaxation buffer containing $0.34 \mathrm{M}$ sucrose. The precipitate thus obtained was used as the NADPH oxidase-rich membrane fraction.

Assays for NADPH Oxidase Activity and p47phox in the Membrane Fraction The membrane fractions were incubated with or without cytosol fractions in the presence and absence of calyculin $\mathrm{A}$ at $25^{\circ} \mathrm{C}$. Aliquots were withdrawn at the indicated times and analyzed for NADPH oxidase activity and $\mathrm{p} 47 \mathrm{phox}$ in the membrane fractions. NADPH oxidase activity was determined as follows: reaction mixtures contained the membrane fraction $(7 \mu \mathrm{g})$, NADPH $(0.1 \mathrm{~mm})$, and cytochrome $\mathrm{c}(50 \mu \mathrm{M})$ in HBSS; the reference cuvette also contained SOD $(30 \mu \mathrm{g})$. The reactions were started by adding NADPH to each cuvette, and changes in absorbance at $550 \mathrm{~nm}$ were monitored at $25^{\circ} \mathrm{C}$. p47phox in the membrane fractions was determined immumochemically as described below. Protein concentrations were measured as described by Lowry et al. ${ }^{19)}$

Immunochemical Detection of p47phox p47phox was measured according to the method described previously ${ }^{18)}$ by using rabbit anti-p47phox antibody. In brief, reaction mixtures containing the membrane fractions were mixed $1: 1$ with lysis buffer [ $2 \%$ sodium dodecyl sulfate (SDS), $30 \%$ glycerol, $10 \%$ 2-mercaptoethanol, and $0.01 \%$ bromophenol blue in $0.25 \mathrm{M}$ Tris- $\mathrm{HCl}, \mathrm{pH} 6.8],{ }^{20)}$ heated at $100^{\circ} \mathrm{C}$ for $3 \mathrm{~min}$, subjected to electrophoresis on $10 \%$ SDS-polyacrylamide gels, electrotransferred to Immobilon (Millipore), blocked for $1 \mathrm{~h}$ with phosphate-buffered saline containing $0.1 \%$ Tween 20 (TPBS) plus 5\% dried milk, and then incubated with anti-p47phox $(1: 5000)$ rabbit polyclonal antibody in TPBS containing $5 \%$ dried milk for $18 \mathrm{~h}$ at $4{ }^{\circ} \mathrm{C}$. Blots were washed with TPBS and incubated with horseradish peroxidase-labeled anti-rabbit IgG (Amersham, UK). Bound antibodies were detected using enhanced chemiluminescence Western blotting detection reagents (Amersham, UK) and Fuji RX medical X-ray film. The integrated optical density of the $47-\mathrm{kDa}$ protein band bound by the anti-p47phox antibody was measured using a scanning densitometer (GT-6000, Epson) and taken to indicate the relative quantity of $\mathrm{p} 47-$ phox. The protein levels in the analyzed samples were within the linear range of density versus concentration (data not shown).

Analysis of Phosphorylated p47phox Reaction mixtures containing the ${ }^{32} \mathrm{P}$-labeled membrane fractions were mixed $1: 1$ with the above lysis buffer, ${ }^{20)}$ heated at $100^{\circ} \mathrm{C}$ for $3 \mathrm{~min}$, and subjected to electrophoresis on $10 \%$ SDS-polyacrylamide gels. Autoradiography was performed at $-85^{\circ} \mathrm{C}$ for $1-2$ weeks with Fuji RX medical X-ray film.

\section{RESULTS}

Effect of Calyculin A on $\mathrm{O}_{2}^{-}$Production of PMA-Stimulated Guinea Pig PMNs The effect of the protein phosphatase inhibitor calyculin $\mathrm{A}$ on $\mathrm{O}_{2}^{-}$production was examined in guinea pig PMNs using PMA as a stimulant. As shown in Fig. 1, when PMNs were incubated with calyculin A at $37^{\circ} \mathrm{C}$ for $5 \mathrm{~min}$ before stimulation with PMA, calyculin $A$ at about $20 \mathrm{~nm}$ showed a weak tendency to inhibit $\mathrm{O}_{2}^{-}$production, but higher concentrations of calyculin $\mathrm{A}$, above 50 $\mathrm{nM}$, enhanced the $\mathrm{O}_{2}^{-}$production in a time-dependent manner. In unstimulated cells, calyculin $A$ by itself had no effect on $\mathrm{O}_{2}^{-}$production. Since the enhancement was marked at 200 $\mathrm{nM}$, we used $200 \mathrm{nM}$ calyculin $\mathrm{A}$ in the following experiments.

Effect of Calyculin A on Translocation of p47phox to the Plasma Membrane of PMA-Stimulated PMNs It has been reported that translocation of $\mathrm{p} 47 \mathrm{phox}$ is essential for activation of NADPH oxidase, and that continuous translocation is necessary to maintain the oxidase in an active state. ${ }^{3)}$ This series of events has been shown to occur after PKC acti- 


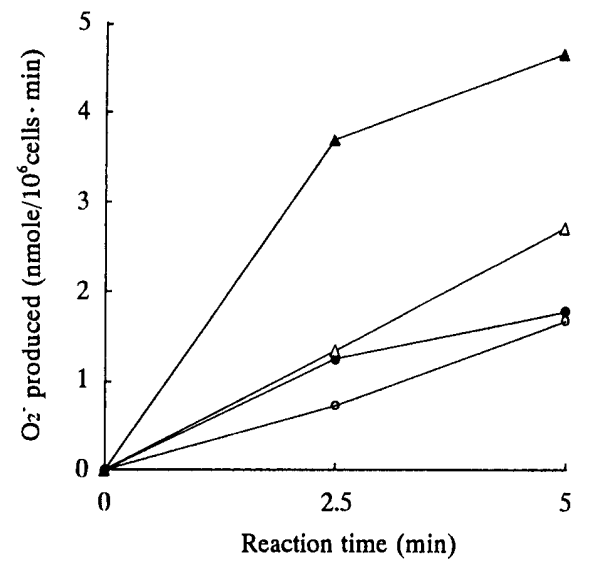

Fig. 1. Effect of Calyculin $\mathrm{A}$ on $\mathrm{O}_{2}^{-}$Production of PMNs Induced by PMA Stimulation

PMNs $\left(10^{7}\right.$ cells $\left./ \mathrm{ml}\right)$ were preincubated in the presence of calyculin A (0: $0 ; 0: 20$; $\triangle: 50 ; \boldsymbol{\Delta}: 200 \mathrm{nM}$ ) in $\mathrm{HBSS}$ at $37^{\circ} \mathrm{C}$ for $5 \mathrm{~min}$, and then $32 \mathrm{nM}$ PMA was added. After further incubation for the indicated times, aliquots of the cell suspensions were withdrawn and assayed for $\mathrm{O}_{2}^{-}$production, as described in Materials and Methods. Values are means from two experiments.
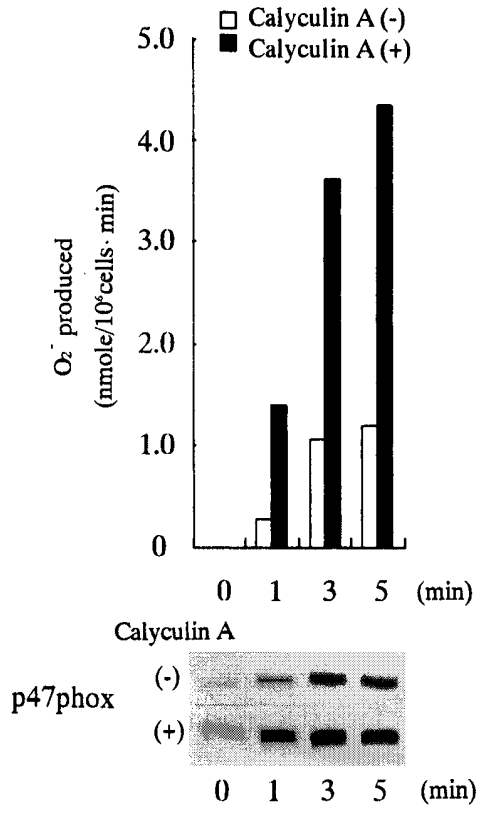

Fig. 2. Effect of Calyculin $\mathrm{A}$ on the Induction of $\mathrm{O}_{2}^{-}$-Producing Activity and Translocation of $\mathrm{p} 47$ phox to the Plasma Membrane Fraction of PMNs Stimulated by PMA

PMNs $\left(10^{7}\right.$ cells $\left./ \mathrm{ml}\right)$ were preincubated in the presence or absence of $200 \mathrm{nM}$ calyculin A in HBSS at $37^{\circ} \mathrm{C}$ for $5 \mathrm{~min}$, and then $32 \mathrm{~nm}$ PMA was added. After further incubation for the indicated times, aliquots of the cell suspensions were withdrawn and analyzed for $\mathrm{O}_{2}^{-}$production (top), and $\mathrm{p} 47 \mathrm{phox}$ in the plasma membrane fractions prepared from the cells was detected immunochemically (bottom), as described in Materials and Methods. Values are means from two experiments.

vation. Therefore, we investigated the effect of calyculin A on the translocation of $\mathrm{p} 47 \mathrm{phox}$ to the membrane fraction after treatment with PMA. The results are shown in Fig. 2. PMA induced translocation of $\mathrm{p} 47 \mathrm{phox}$ to the membrane fraction with a time course corresponding to that of $\mathrm{O}_{2}^{-}$production. Moreover, the translocation of $\mathrm{p} 47 \mathrm{phox}$, in parallel with $\mathrm{O}_{2}^{-}$production, was markedly increased by preincubation of PMNs with calyculin A. These results suggest that the increased amounts of $\mathrm{p} 47 \mathrm{phox}$ in membrane fractions resulting from calyculin A treatment, leads to the acceleration of $\mathrm{O}_{2}^{-}$production.

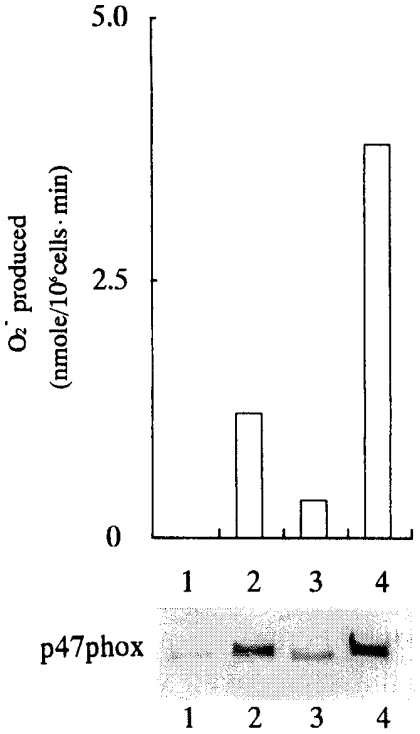

Fig. 3. Effect of $\mathrm{H}-7$ and Calyculin $\mathrm{A}$ on $\mathrm{O}_{2}^{-}$Production and Translocation of 47 phox to the Plasma Membrane Fraction of PMNs after PMA Stimulation

PMNs $\left(10^{7}\right.$ cells $\left./ \mathrm{ml}\right)$ were incubated at $37^{\circ} \mathrm{C}$ in the presence of $32 \mathrm{nM}$ PMA for $0 \mathrm{~min}$ (sample 1) or $3 \mathrm{~min}$ (sample 2). After $3 \mathrm{~min}$ of incubation, the reaction mixtures were supplemented with $200 \mu \mathrm{M} \mathrm{H}-7$ and incubated for $5 \mathrm{~min}$ at $37^{\circ} \mathrm{C}$ (sample 3), and were then supplemented with $200 \mathrm{~nm}$ calyculin $\mathrm{A}$ and further incubated for $5 \mathrm{~min}$ at $37^{\circ} \mathrm{C}$ (sample 4). Samples 1, 2,3, and 4 were analyzed for $\mathrm{O}_{2}^{-}$production (top), and $\mathrm{p} 47 \mathrm{phox}$ was detected immunochemically in plasma membrane fractions prepared from the sample (bottom) as described in Materials and Methods. Values are means from two experiments.

Effects of Calyculin $A$ and $\mathrm{H}-7$ on Activation of NADPH Oxidase We next investigated whether the activation of NADPH oxidase is reversible, and whether p47phox is reversibly and repeatedly translocated to the membrane fraction. To answer these questions, we examined the effects of $\mathrm{H}-7$, a PKC inhibitor, ${ }^{21)}$ and of calyculin A (Fig. 3). When PMNs were stimulated with PMA for $3 \mathrm{~min}, \mathrm{O}_{2}^{-}$production and translocation of $\mathrm{p} 47 \mathrm{phox}$ to the membrane fraction were observed. Addition of H-7 $(200 \mu \mathrm{M})$ to PMNs for $5 \mathrm{~min}$ after stimulation with PMA resulted in reduction of both the amount of $\mathrm{p} 47$ phox on the plasma membrane and $\mathrm{O}_{2}^{-}$production. Next, when calyculin A was added to PMA-stimulated PMNs, which were then treated with $\mathrm{H}-7$ for $5 \mathrm{~min}, \mathrm{O}_{2}^{-}$production and translocation of $\mathrm{p} 47 \mathrm{phox}$ to the membrane fraction were observed again, indicating that reconstitution of active NADPH oxidase occurred.

Effect of Calyculin A on Decrease and Dephosphorylation of p47phox in the Membrane Fraction of PMA-Stimulated PMNs, and Inactivation of NADPH Oxidase by the Cytosol Fraction To investigate the involvement of protein phosphatase in the regulation of NADPH oxidase activity, we examined the effect of calyculin A on the NADPH oxidase activity of membrane fractions obtained from PMA-stimulated PMNs. When the membrane fraction was incubated with the cytosol fraction for $20 \mathrm{~min}$ at $25^{\circ} \mathrm{C}$, NADPH oxidase activity was rapidly reduced. However, the reduction of NADPH oxidase activity by the cytosol fraction was markedly inhibited by $200 \mathrm{~nm}$ calyculin A (Fig. 4A). Furthermore, we determined the effect of incubation with the cytosol fraction in the presence or absence of calyculin $\mathrm{A}$ on the amount of p47phox in the membrane fraction (Fig. 4B). After incubation of the PMA-stimulated membrane fraction 
(A)

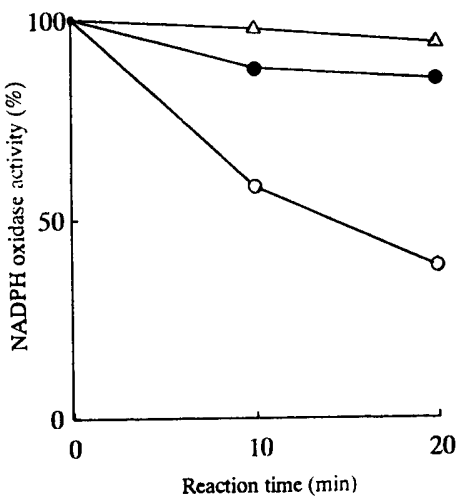

(B)

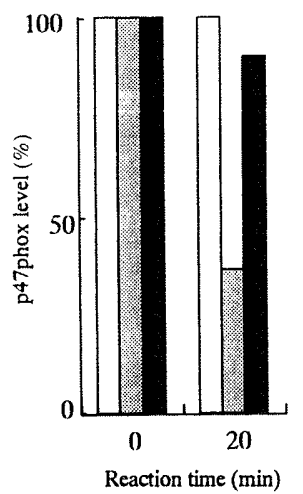

(C-1)

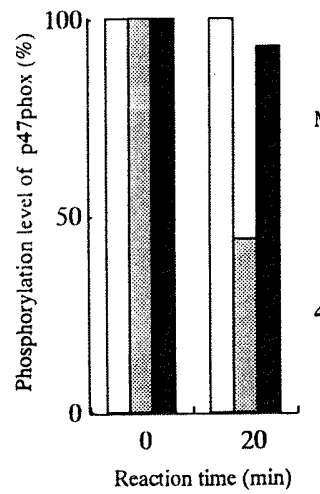

(C-2)

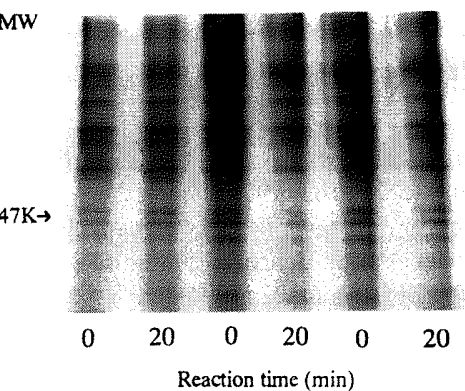

Fig. 4. Effect of Cytosol Fraction and Calyculin A on Stability of NADPH Oxidase Activity, Content of p47phox and Phophorylation Level of p47phox in Plasma Membrane Fractions

The NADPH oxidase-rich membrane fractions and cytosol fractions were prepared as described in Materials and Methods. The membrane fractions were incubated with (, $\mathrm{O}^{\circ}$ $\mathbf{E}, \mathbf{\mathbf { u }} ; \mathrm{b}, \mathrm{c})$ or without $\left(\triangle ; \square ;\right.$ a) cytosol fraction in the presence $(\mathbf{0} ; \mathbf{\square} ; \mathrm{c})$ or absence $(O, \triangle ; \square, \mathbf{\square} ; \mathrm{a}, \mathrm{b})$ of 200 nM calyculin $\mathrm{A}$ at $25^{\circ} \mathrm{C}$. The reaction mixtures were withdrawn at the indicated times, membrane fractions were separated by centrifugation at $85000 \mathrm{~g}$ for $30 \mathrm{~min}$, and then analyzed for NADPH oxidase activity (A), p47phox level (B) and level of phosporylation of $\mathrm{p} 47$ phox $(\mathrm{C}-1)$ in the membrane fractions. Values are means from two experiments. $\mathrm{C}-2$ : autoradiograph of membrane fraction.

with or without the cytosol fraction for $20 \mathrm{~min}$, the amount of p47phox in the membrane fraction was found to be reduced in the presence of the cytosol fraction. However, the disappearance of $\mathrm{p} 47$ phox from the membrane fractions was suppressed by calyculin A. Similarly, the level of phosphorylation of the $\mathrm{p} 47 \mathrm{phox}$ in the membrane fraction was decreased by the addition of the cytosol fraction, but this reduction was largely inhibited by calyculin A (Fig. 4C). Thus, good correlation among the p47phox levels, the phosphorylation of p47phox, and NADPH oxidase activity was observed in the membrane fraction obtained from PMA-stimulated PMNs upon incubation with or without cytosol in the presence or absence of calyculin A. These results suggest that inactivation of NADPH oxidase is, at least in part, due to cytosolic protein phosphatase.

\section{DISCUSSION}

In the present study, we examined the relationship between NADPH oxidase activation and translocation of $\mathrm{p} 47 \mathrm{phox}$, one of the cytosolic activation factors of NADPH oxidase in PMNs, to the plasma membrane in PMA-treated guinea pig PMNs in the presence or absence of calyculin A. Pretreatment of PMNs with calyculin A markedly enhanced PMAinduced $\mathrm{O}_{2}^{-}$production and translocation of $\mathrm{p} 47 \mathrm{phox}$ to the membrane fraction. Addition of $\mathrm{H}-7$ to PMA-stimulated PMNs inhibited $\mathrm{O}_{2}^{-}$production and translocation of $\mathrm{p} 47$ phox to the membrane fraction, and subsequent supplementation with calyculin A caused the recovery of $\mathrm{O}_{2}^{-}$production and translocation of $\mathrm{p} 47 \mathrm{phox}$. The activity of NADPH oxidase, the content of p47phox and the phosphorylation level of p47phox in membranes prepared from PMA-stimulated PMNs were decreased by the addition of the cytosol fraction. These reductions may due to cytosolic protein phosphatase.

It is generally thought that $\mathrm{p} 47 \mathrm{phox}$ is translocated to the plasma membrane from the cytosol through phosphorylation of $\mathrm{p} 47 \mathrm{phox}^{4-9)}$ by PKC. Yamaguchi et al. ${ }^{11,12)}$ reported that the $\mathrm{p} 47$ phox phosphorylated by a PKC preparation was dephosphorylated by incubation with the cytosol fraction obtained from resting neutrophils and that the dephosphoryla- tion was largely inhibited by both okadaic acid and calyculin A. We agree with Ding and Badwey ${ }^{10)}$ in thinking that the assembly of the oxidase complex is involved in the phosphorylation dephosphorylation cycle that may regulate $\mathrm{p} 47 \mathrm{phox}$. That is, in resting cells, phosphorylation and dephosphorylation of p47phox may be at equilibrium, but stimulation of PMNs with agents such as PMA, a PKC activator, promotes phosphorylation of $\mathrm{p} 47 \mathrm{phox}$ and induces its redistribution to the plasma membrane. Under these conditions, addition of $\mathrm{H}-7$, a PKC inhibitor, markedly inhibited phosphorylation of p47phox and activation of NADPH oxidase, and decreased the amount of $\mathrm{p} 47$ phox in the membrane fraction. Subsequent addition of calyculin $\mathrm{A}$, a protein phosphatase inhibitor, suppressed the effects of $\mathrm{H}-7$, that is, restored the activation of NADPH oxidase and translocation of $\mathrm{p} 47 \mathrm{phox}$ to the membrane fraction, indicating that the activation of NADPH oxidase can occur again even after the enzyme activity is lost once. Moreover, as shown in Fig. 4, when the membrane fraction obtained from PMA-stimulated PMNs was incubated without any addition, the activity of NADPH oxidase, the amount of p47phox and the phosphorylation level of $\mathrm{p} 47 \mathrm{phox}$ in the membrane fraction were not altered. However, in the presence of the cytosol fraction, the activity of NADPH oxidase, the amount of p47phox and the phosphorylation level of $\mathrm{p} 47 \mathrm{phox}$ in the membrane fraction were greatly decreased. These reductions were markedly attenuated by the addition of calyculin $\mathrm{A}$. These findings indicate that the cytosolic protein phosphatase that controls the conversion of the active form of NADPH oxidase to the inactive form is present in the cytosol fraction, but not in the membrane fraction, and that phosphorylated $\mathrm{p} 47 \mathrm{phox}$, which is located in the membrane fraction, that is, which is translocated to the membrane, may also be dephosphorylated by this cytosolic protein phosphatase.

We have shown here that the active form of NADPH oxidase is recovered even after the active complex has been inactivated once, and that dissociation of the p47phox subunit from the activated NADPH oxidase complex is caused by dephosphorylation of phosphorylated $\mathrm{p} 47 \mathrm{phox}$ by cytosolic protein phosphatase. Further studies to identify the protein 
phosphatase contributing to this regulation of the activation and inactivation of NADPH oxidase and to determine the behavior of the p67phox subunit of activated NADPH oxidase during dissociation of p47phox from the activated enzyme by dephosphorylation are needed.

\section{REFERENCES}

1) Goldstein I. M., Roos D., Kaplan H. B., Weissmann G., J. Clin. Invest., 56, 1155-1163 (1975).

2) Rossi F., Biochim. Biophys. Acta, 853, 65-89 (1986).

3) Chanock S. J., Benna J. E., Smith R. M., Babior B. M., J. Biol. Chem., 269, 24519-24522 (1994).

4) Clark R. A., Malech H. L., Gallin J. I., Nunoi H., Volpp B. D., Pearson D. W., Nauseef W. M., Curnutte J. T., N. Engl. J. Med., 321, 647-652 (1989).

5) Heyworth P. G., Segal A. W., Biochem. J., 239, 723 -731 (1986).

6) Okamura N., Curnutte J. T., Roberts R. L., Babior B. M., J. Biol. Chem., 263, 6777—6782 (1988).

7) Volpp B. D., Nauseef W. M., Donelson J. E., Moser D. R., Clark R. A., Proc. Natl. Acad. Sci. U.S.A., 86, 9563 (1989).

8) Rotrosen D., Leto T. L., J. Biol. Chem., 265, 19910-19915 (1990).

9) Ohtsuka T., Nakamura M., Hiura M., Yoshida K., Okamura N., Ishibashi S., J. Biochem., 108, 169-174 (1990).
10) Ding J., Badwey J. A., J. Biol. Chem., 267, 6442-6448 (1992).

11) Yamaguchi M., Sasaki J., Kuwana M., Sakai M., Okamura N., Ishibashi S., Arch. Biochem. Biophys., 306, 209-214 (1993).

12) Yamaguchi M., Saeki S., Yamane H., Okamura N., Ishibashi S., Biochem. Biophys. Res. Commun., 216, 203-208 (1995).

13) Ishihara H., Martin B. L., Brautigan D. L., Karaki H., Ozaki H., Kato Y., Fusetani N., Watabe S., Hashimoto K., Vemura D., Hartshorne D. J., Biochem. Biophys. Res. Commun., 159, 871—877 (1990).

14) Ishihara H., Ozaki H., Sato H., Karaki H., Watabe S., Fusetani N., Hashimoto K., Vemura D., Hartshorne D. J., J. Pharmacol. Exp. Ther., 250, 388-398 (1989).

15) Sbarra A. J., Karnovsky M. L., J. Biol. Chem., 234, 1355-1362 (1959).

16) Okamura N., Ohashi S., Nagahisa N., Ishibashi S., Arch. Biochem. Biophys., 228, 270-277 (1984).

17) Market M., Andrews P. C., Babior M. B., "Methods in Enzymology," Vol. 105, ed. by Packer L., Academic Press, Orlando, FL, 1984, pp. $358-365$.

18) Kawakami N., Takemasa H., Yamaguchi T., Hayakawa T., Shimohama S., Fujimoto S., Arch. Biochem. Biophys., 349, 89-94 (1998).

19) Lowry O. H., Roebrough N. J., Ranadall R. J., J. Biol. Chem., 193, $265-275(1951)$.

20) Laemmli U. K., Nature (London), 227, 680-685 (1990).

21) Hidaka H., Inagaki M., Kawamoto S., Sasaki Y., Biochemistry, 23, $5036-5041(1984)$. 